\title{
駆動源との相互作用を考慮した回転軸系の 最適運転曲線に関する研究*
}

\author{
山川 宏**, 酉弣康志***, 鉿木良明****

\section{A Study on the Optimum Operating Curve for Rotating Shaft Systems under Consideration of the Effect of Limited Power Supply}

\author{
Hiroshi YAMAKAWA, Yasushi NISHIOKA, and Yoshiaki SUZUKI
}

\begin{abstract}
There exist comparatively few studies on the dynamic behavior of rotating systems with limited power supply when passing through the critical speed. However, little work has been done on the deterimum operating curve of such systems to minimize the maximum whirl deflections yielded just after passing through the critical speed. In this study, a new method of dynamic analysis is presented in which both Newmark's $\beta$ method and Newton-Raphson's method are utilized. Then, from a practical point of view, optimum operating curves are studied by making
use of an optimization technique.
\end{abstract}

Key Words: Vibration of Rotating Body, Limited Power Supply, Critical Speed, Optimum Operating Curve, Dynamic Analysis, Optimization

\section{1. 緒紓}

回転機械の中には構造的に種々の制約を受け，回転 の動力源に十分な出力の余裕を持たせることが国難と なる場合が見うけられる。余裕のないトルクで運転す る回転軸系の挙動は駆動トルクの影蔧を受けやすい。 特に加速運転では，危険速度通過時のふれまわり仍加 速時の加速度にその影䛚が顕著に現れる.このような 現象を解析する上で，さらに設計上の限界駆動トルク を知るためにも，駆動源との相互作用を考虑した解析 が必要となる。

従来, 回転軸系の振動問題の中で危険速度通過問題 を取扱った研究は数多くある。それらの研究のうちで 駆動源との相互作用を考虑に入れた研究は，1964年 にKononenkoによって漸近法を用いた非定常振動時 の解析 ${ }^{(1)}, 1974$ 年の岩壱, 神吉, 川井らに上る非対称 回転軸に関しての解析および実験がある(2)。また 1977 年には，野波，宮下らが漸近法を用いた方法によりジ

\footnotetext{
*昭和 61 年 8 月 21 日 第 938 回講演会に㧍いて講演，原稿受 付 昭和 61 年 3 月 6 日。

** 正員, 早稲田大学理工学部 (通160 東京都新宿区大久保 3-41).

*****准员, 住友金属工業(株)（画554 大阪市此花区息屋 5-1-109).

**** 准員, ソニー(株) (再243 厚木市地町 4-14-1).
}

ヤイロ効果の影䅧を解明し (3), 矢鍋は駆動トルクの影 暃を明らかにした (4).をして 1977 年には松浦が不釣合 定数を用いて非定常特性の検討を行っている(5). しか しながら駆動源との相互作用を考慮し，かつ運転曲線 の最邀な加速方法を検討した研究例はほとんどない. そこで本研究では，駆動源との相互作用，減衰など を考慮に入れた回転軸系の動的応答問題の解析法とし て, ニューマークの $\beta$ 法とニュートン・ラプソン法を 併用した方法をまず提示する。しかる後危険速度通過 時の最大ふれまわり振幅の抑制を目的とした最適運転 曲線を検討し，これらの結果を実験により一部検証し t.

\section{記 号}

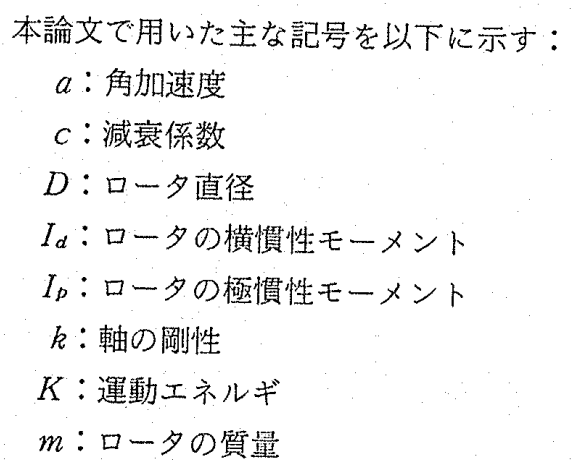


$r:$ ふままりり振幅

$T:$ 駆動卜ルク

$t_{s t}:$ 角速度の停留時間

$V:$ ポテンシャルエネルギ

$\varepsilon:$ 偏心量

$\theta:$ 重心 Gの回転角

$\varphi$ : ロータの傾き角

$\varphi_{x}: \varphi$ の $y z$ 平面への投影

$\varphi_{y}: \varphi$ $\varphi z$ 平面への投影

$\omega:$ 角速度

$\omega_{s t}$ :角速度の停留値

\section{2. 駆動源との相互作用を考慮した 回転軸系の動的応答解析}

2・1 運動方程式回転軸系を多自由度系に近似 して以下に行うものとほほ同様の解析も可能である が，本研究では問題の本質を把握しやすくするため に，図1に示すような両端を軸受 A，Bで支持された 基本ロータモデルを考え，以下に示す仮定を置く。

(i ）ロータの剛体円板が軸に垂直に取付けられて いるとし，軸質埋は無視する。

(ii) 軸受は剛軸受とする。

(iii）ロー夕の並進運動に比例する外部減衰を考 え, 内部減衰は無視する。

図 1 では質量 $m$ のロータが軸中心 $S$ で固定されて

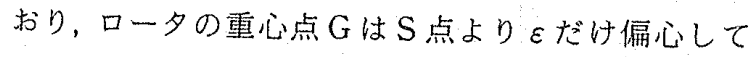
いる(図 2 )。回転軸の長さを $l$ とし，簡単のために一 様断面とする。さて軸に対するロータの傾き角を $\varphi$ と してその $y z$ 平面, $x z$ 平面への投影を $\varphi_{x}, \varphi_{y}$ とし, 軸の回転が非定常でしかも軸の変形が微小と仮定すれ ば系に蓄えられる運動エネルギは，結局次式にて表せ られる(6)。

$$
\begin{aligned}
K & =\frac{1}{2}\left[m \left\{\dot{x}^{2}+\dot{y}^{2}+\varepsilon^{2} \dot{\theta}^{2}+2 \varepsilon \dot{\theta}(\dot{y} \cos \theta\right.\right. \\
& -\dot{x} \sin \theta)\}+I_{d}\left(\dot{\varphi}_{x}^{2}+\dot{\varphi}_{y}^{2}\right) \\
& \left.+I_{p}\left\{\dot{\theta}^{2}-\dot{\theta}\left(\varphi_{x} \dot{\varphi}_{y}-\dot{\varphi}_{x} \varphi_{y}\right)\right\}\right]
\end{aligned}
$$

ここに $x, y$ は軸中心 $\mathrm{S} の$ 座標で, $\theta$ は重心 $\mathrm{G}$ の回転 角， $I_{d}, I_{p}$ 㳉それぞれロータの横慣性モーメントと極 㥽性モーメントである。束た系に篦えら扎るポテンシ ヤルエネルギ $V$ は

$$
\begin{aligned}
V & =\frac{1}{2} k_{11}\left(x^{2}+y^{2}\right)+k_{12}\left(y \varphi_{x}-x \varphi_{y}\right) \\
& +\frac{1}{2} k_{22}\left(\varphi_{x}^{2}+\varphi_{y}^{2}\right)-T \theta \ldots \ldots \ldots \ldots \ldots \ldots
\end{aligned}
$$

となる(6). 上式中 $k_{11} ， k_{12}, k_{22}$ は，輠のせん断力上曲
げモーメントをたわみおよびたわみ角と下記のように 関係付ける軸の魝性である。またTは駆動トルクであ 子.

$$
\left\{\begin{array}{l}
F_{x} \\
M_{y} \\
F_{y} \\
M_{x}
\end{array}\right\}=\left[\begin{array}{cccc}
k_{12} & -k_{12} & 0 & 0 \\
-k_{12} & k_{22} & 0 & 0 \\
0 & 0 & k_{11} & k_{12} \\
0 & 0 & k_{21} & k_{22}
\end{array}\right]\left\{\begin{array}{l}
x \\
\varphi_{y} \\
y \\
\varphi_{x}
\end{array}\right\}
$$

式(1)，（2）の結果を減衰の消散項の存在するラグ ランジュの運動方程式に代入すれば，次の五つの基礎 となる運動方程式を得る：

$$
\begin{aligned}
& \left\{\begin{array}{c}
\left(I_{p}+m \varepsilon^{2}\right) \ddot{\theta}=T+m \varepsilon(\ddot{x} \sin \theta-\ddot{y} \cos \theta) \\
-\frac{1}{2} I_{p}\left(\ddot{\varphi}_{x} \varphi_{y}-\varphi_{x} \ddot{\varphi}_{y}\right) \cdots \cdots \cdots \cdots \cdots(4)
\end{array}\right. \\
& m \ddot{x}+c \dot{x}+k_{11} x-k_{12} \varphi_{y}=m \varepsilon(\ddot{\theta} \sin \theta \\
& \left.+\dot{\theta}^{2} \cos \theta\right) \\
& m \ddot{y}+c \dot{y}+k_{12} y+k_{12} \varphi_{x}=m \varepsilon\left(\dot{\theta}^{2} \sin \theta\right. \\
& -\ddot{\theta} \cos \theta \text { ) } \\
& I_{d} \ddot{\varphi}_{x}+I_{p} \dot{\theta} \dot{\varphi}_{y}+k_{12} y+k_{22} \varphi_{x}=-\frac{1}{2} I_{p} \ddot{\theta} \varphi_{y} \\
& I_{d} \ddot{\varphi}_{y}-I_{p} \dot{\theta} \dot{\varphi}_{x}-k_{12} x+k_{22} \varphi_{y}=\frac{1}{2} I_{p} \ddot{\theta} \varphi_{x}
\end{aligned}
$$

$2 \cdot 2$ 時刻歴応答解析運動方程式 (4) ( 8 ) は $x, y, \varphi_{x}, \varphi_{y}, \theta$ を変数とする連立の非線形微分方程

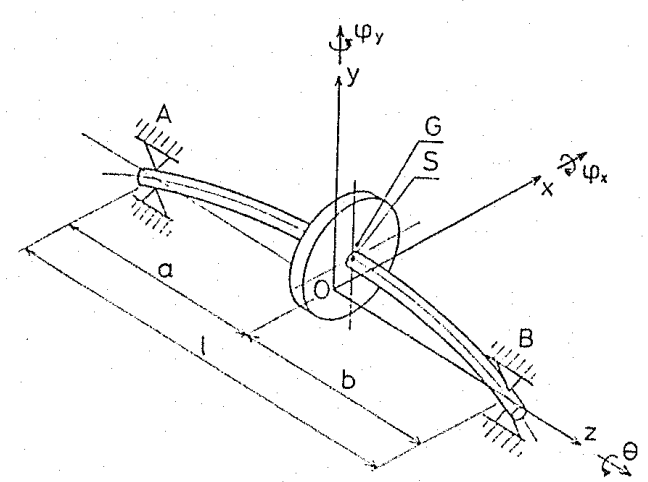

図 1 基本ロータ系モデル

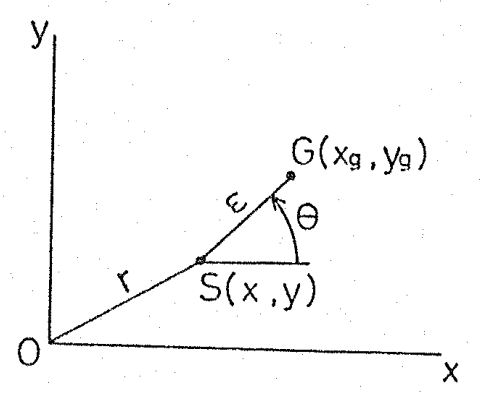

図 2 口-夕0偳心 
式である。非線形性を区分線形化することによって逐 次程分法ですべての变数に対して数值解を得ることも 可能亡考えら机るが，その精度は一般的によくなくま た計算の手間がかかる上に見通しもよくない。をこで 本研究で，変数 $\theta$ の項の放が非線形であることに着 目して他の変数 $x, y, \varphi_{x}, \varphi_{y} に=z ー マ-\eta の \beta$ 法 学適用して, 時刻 $t$ より微小時間経過後の $t+\Delta t$ に抢 ける $\theta$ のみ関する方程式崖導き，てれをニュート ン・ラプソン法にて解く方法を以下に提示する。

ニューマークの $\beta$ 法では, 時刻 $t+\Delta t$ の变位べク トル $\boldsymbol{q}(t+\Delta t)$ と速度べクトル $\dot{\boldsymbol{q}}(t+\Delta t)$ は, $\beta=1 / 4$ とすれば

$$
\left\{\begin{array}{r}
\boldsymbol{q}(t+\Delta t)=\boldsymbol{q}(t)+\Delta t \dot{\boldsymbol{q}}(t)+\frac{(\Delta t)^{2}}{2} \ddot{\boldsymbol{q}}(t) \\
+\frac{(\Delta t)^{2}}{4} \ddot{\boldsymbol{q}}(t+\Delta t) \quad \ldots \ldots \ldots \cdots \cdots(9) \\
\dot{\boldsymbol{q}}(t+\Delta t)=\dot{\boldsymbol{q}}(t)+\frac{\Delta t}{2} \ddot{\boldsymbol{q}}(t)+\frac{\Delta t}{2} \dot{\boldsymbol{q}}(t+\Delta t) \\
\ldots \ldots \cdots \cdots(10)
\end{array}\right.
$$

と表される. いま $\boldsymbol{q}=\left\{x, y, \varphi_{x}, \varphi_{y}\right\}^{T}$ と考えて连動 方程式 $(4) \sim(8)$ を次の手順に従って変形する.

[手順 1]

式( 7$),(8)$ から $\varphi_{x}(t+\Delta t), \varphi_{y}(t+\Delta t)$ を末知量 $\dot{\theta}(t+\Delta t), x(t+\Delta t), y(t+\Delta t)$ と時刻 $t$ の既知量を 用いて表す。

[手順 2)

手順 1 で得られた $\varphi_{x}(t+\Delta t), \varphi_{y}(t+\Delta t)$ を式 $(5)$, (6)に代入する.この結果 $\ddot{x}(t+\Delta t), \ddot{y}(t+\Delta t)$ は末 知量 $\ddot{\theta}(t+\Delta t), \dot{\theta}(t+\Delta t), \theta(t+\Delta t)$ および時刻 $t$ の 既知量で表される。

[手順 3]

手順 1 ，手順 2 で得られた関係を式 (4)に代入して $\dot{\theta}(t+\Delta t)$ のみの非線形方程式を導く.

計算が煩雑となるので途中経過は省略するが，上記 の手順によって得られる最終的な式は以下の形をと る.

$$
\begin{aligned}
& a_{7} \dot{\theta}^{7}(t+\Delta t)+a_{6} \dot{\theta}^{6}(t+\Delta t)+a_{5} \dot{\theta}^{5}(t+\Delta t) \\
& +a_{4} \dot{\theta}^{4}(t+\Delta t)+a_{3} \dot{\theta}^{3}(t+\Delta t)+a_{2} \dot{\theta}^{2}(t+\Delta t) \\
& +a_{1} \dot{\theta}(t+\Delta t)+a_{0}+\left\{b_{6} \dot{\theta}^{6}(t+\Delta t)+b_{5} \dot{\theta}^{5}(t\right. \\
& +\Delta t)+b_{4} \dot{\theta}^{4}(t+\Delta t)+b_{3} \dot{\theta}^{3}(t+\Delta t) \\
& +b_{2} \dot{\theta}^{2}(t+\Delta t)+b_{1} \dot{\theta}(t+\Delta t) \\
& \left.+b_{0}\right\} \sin \left\{d_{1} \dot{\theta}(t+\Delta t)+d_{0}\right\} \\
& +\left\{c_{6} \dot{\theta}^{6}(t+\Delta t)+c_{5} \dot{\theta}^{5}(t+\Delta t)\right. \\
& +c_{4} \dot{\theta}^{4}(t+\Delta t)+c_{3} \dot{\theta}^{3}(t+\Delta t)+c_{2} \dot{\theta}^{2}(t+\Delta t) \\
& \left.+c_{1} \dot{\theta}(t+\Delta t)+c_{0}\right\} \cos \left\{d_{1} \dot{\theta}(t+\Delta t)+d_{0}\right\} \\
& =0
\end{aligned}
$$

$こ こ に a_{0} \sim a_{7}, b_{0} \sim b_{7}, c_{0} \sim c_{7}, d_{0}, d_{1}$ \&, 特刻 $t の$ 諸連な含む係数である。組面の都合上，各係数の具体 形は省くが，減衰やジャイロ効果の関保項を组視すれ ばその形は簡粍になる。

ところで式(11)は， $\dot{\theta}(t+\Delta t)$ に関して 7 次式で, しかも $\sin , \cos の$ 関数の中にも $\dot{\theta}(t+\Delta t)$ を含む非線 形の方程式である。しかしその係数の微分が比較的容 易に計算できるのでニュートン・ラプソン法によって 効率のよい，精度の高い解を得ることができる。

\section{2・3，駆動トルク特性と運転曲線を考留した解析}

回転機械のトルク特性は，一般に回転数の増加に伴い トルクが減少してゆく、いわゆる右下り特性のものが 多い.したがって駆動源に十分な出力余裕を持たせる ことができない場合には，危険速度通過の際に，大き なふれまわりにより危険速度を越えられない場合も生 じてくる。かかる場合は駆動卜ルク特性を考慮した解 析が必要である。運動方程式 (4)により, 駆動トルク $T$ は，ふれまわりと加速の両方に消費されることが わかる、その様子を図 3 にて例示すると, 区間 A と C では運転曲線で設定した加速度で加速可能であるが区 間Bではトルクの右下りの特性（図の $T_{s}$ の直線）の 制限を受けるため，設定した加速度 $a$ を維持できずに $a_{s}$ に鈍る。

以上述べた駆動トルク特性や運転曲線の加速の方法 を考えて前項の時刻歴応答解析を行う解析手順を図 4 の流れ図にまとめて示す。

\section{3. 運転曲線の最適化}

危険速度通過時の回転軸系のふれまわり振幅を最小 にするような運転曲線の形態は工学上興味深いものと 考えられる。一般的な運転曲線の最適化を考える前に いくつかの運転曲線を試行的に設定し，その危険速度 通過時のふれまわり振幅を前章の計算方法で求める一

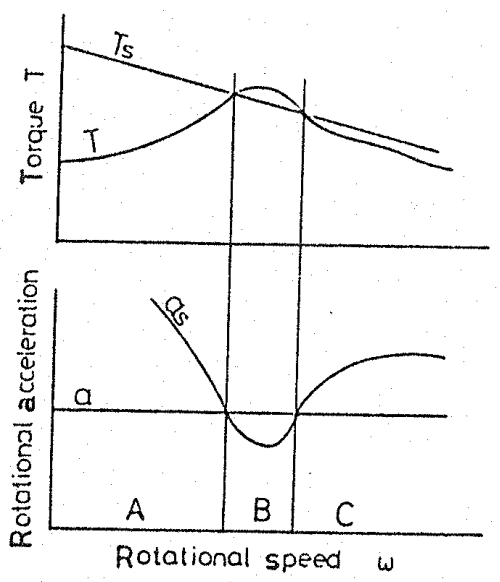

図 3 駆動トルクの加速度への影響 
方, 後述の㬰験装置を使用し，一部実験的にも検討を 行い，危険速度通過の可否，ふれまわり振幅，トルク 特性などを比較した。それらの結果の詳細は割愛する が，それらの結果と実際の運転曲線として直線的な加 速が比較的設定しやすいことなどを考虑に入れれば， まず一定加速度で上昇させ，危険速度の直前で一端停 留させ，再び一定加速度で上昇させ危険速度を越える 型の運転曲線は，ふれまわり振幅抑制には効果のある 運転曲線の一つであると考えられる，そこで本研究で は，図 5 に示すような運転曲線に着目して，一時的に 加速を停留させる角速度 $\omega_{s t}$ とその停留時間 $t_{s t}$ を設 計変数にとり,危険速度通過時のふれまわり振幅の最 大值を最小化する最適設計問題を設定し（表 1)，それ を傾斜降下法を用いて解き，最適值を求めた。すなわ ち最大ふれまわりの設計変数に関する傾斜の方向を計 算してその方向に $\omega_{s t}$ と $t_{s t}$ の初期值から改良を進め ていく方法を採った。

\section{4. 実験}

上記の解析結果の検証と運転曲線の実用性を調べる ために図 5 のようなモデル装置を作成して実験を行っ た。この装置では，両端を玉軸受で支持され，中央部 にロータを有する SCM 22 材の軸が DC モータで駆動

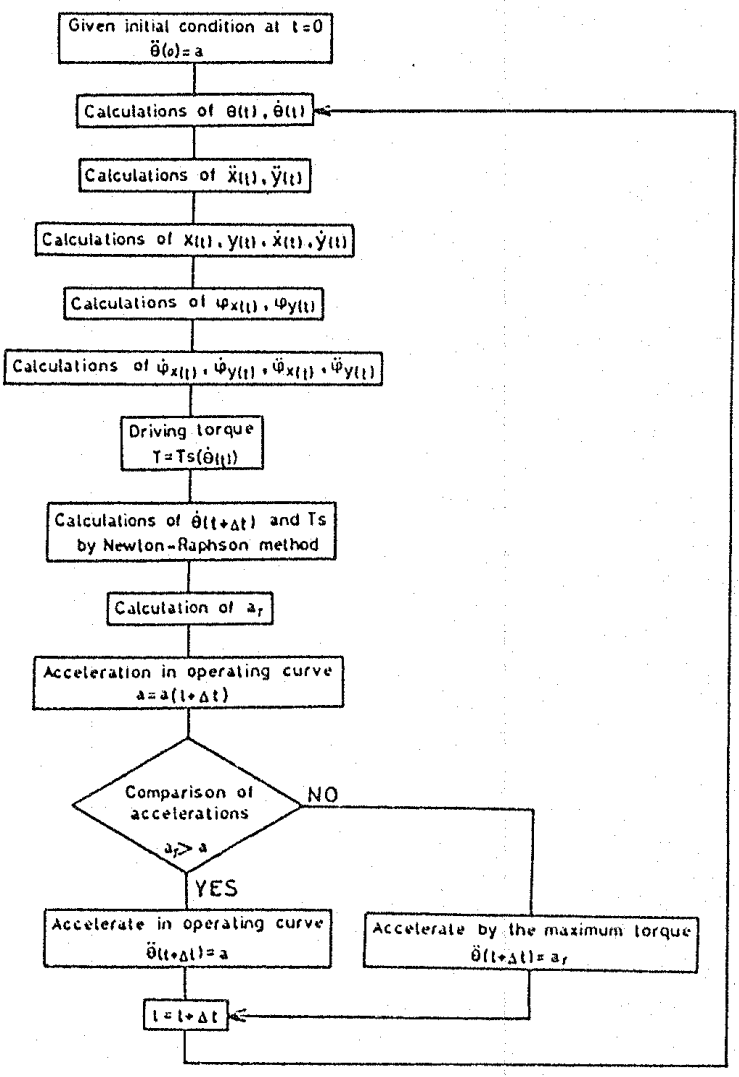

図 4 㭙刻嘿応答解析手㮌
されている，DCモータの回転数はパソコンによって 制御され，図 6 の運転曲線を含む各種の運転曲線が設 定できるようになっている。軸の水平㧍よび垂直方向 の変位は，それぞれの方向に配した非接触の微小変位 計にて測定され，併せてトルクも測定できるようにな っている.

\section{5. 数 値 計算結果}

上記の動的応答解析法および最適設計法に対して具 体的に数値計算を行い，一部実験結果と比較したもの を以下に示そう。対象としては図 5 に示したロー夕軸 系を取り上げ，ロータの直径 $D$, ヤング率 $E$, 密度 $\rho$ などは以下の值を用いた。なおこのロー夕軸系の危険

表 1 最適設計問題

\begin{tabular}{c|cc}
\hline $\begin{array}{c}\text { Design } \\
\text { variable }\end{array}$ & $\begin{array}{l}\text { Rotational } \\
\text { speed }\end{array} \omega_{s t}$, & Time $t_{s t}$ \\
\hline $\begin{array}{c}\text { Condition } \\
\text { of } \\
\text { constrainis }\end{array}$ & $\begin{array}{l}\text { Rotational } \\
\text { accereration }\end{array}$ & $\begin{array}{c}\text { Characteristics of } \\
\text { driving torque }\end{array}$ \\
\hline $\begin{array}{c}\text { Objective } \\
\text { function }\end{array}$ & $\begin{array}{c}\text { Max } \\
\text { whirl } \\
\text { displacement }\end{array}$ \\
\hline $\begin{array}{c}\text { Optimum } \\
\text { design } \\
\text { problem }\end{array}$ & $\begin{array}{c}\text { Minimization } \\
\text { of } \\
r_{\text {max }}\end{array}$ \\
\hline
\end{tabular}

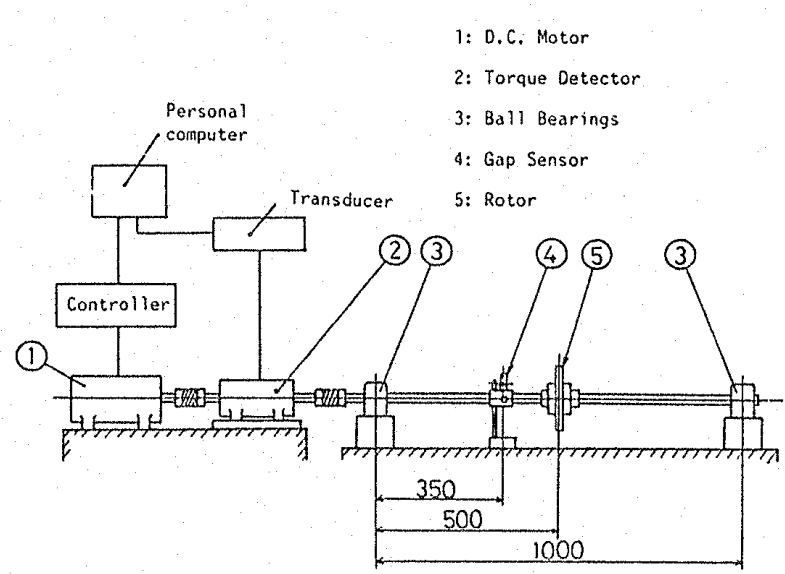

図 5 实験装晸

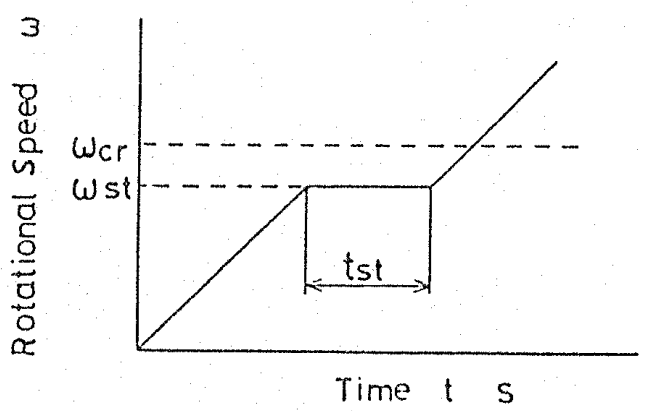

図 6 刘象连転晽線 
速度は計算によると $\omega_{c r}=253.2 \mathrm{rad} / \mathrm{s}$ とった。

$\begin{array}{lrr}D \text { (Diameter) } & =20 & \mathrm{~mm} \\ E \text { (Young's modulus) }=206 & \mathrm{GPa} \\ \rho \text { (Density) }=7.80 \times 10^{3} & \mathrm{~kg} / \mathrm{m}^{3}\end{array}$

$5 \cdot 1$ 危険速度通過の際の時刻歴応答 定加速诸 転の際の危険速度通過付近の洼刻歴忍答とトルク园 7 , 図 8 に示す。減衰と㣂重心はそれそれ $\zeta=0.05$ ， $=0.1$ で計算した。図 7 では駆動源のトルク特性は $T$

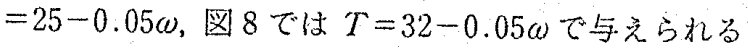
右下りの直線特性で大きさの異るもの用いた。図7 ではトルクに余裕があるために設定した加速磨に従っ
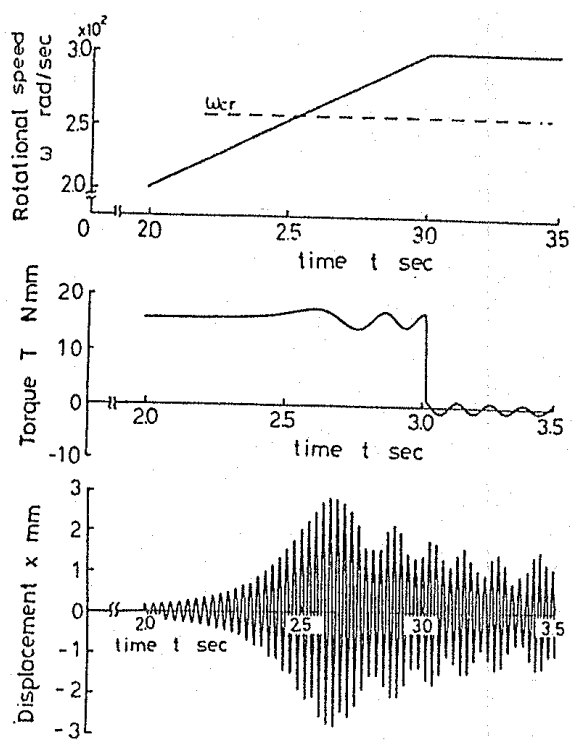

図 7 時刻歴応答と駆動トルク（定加速運転トルク制限小）
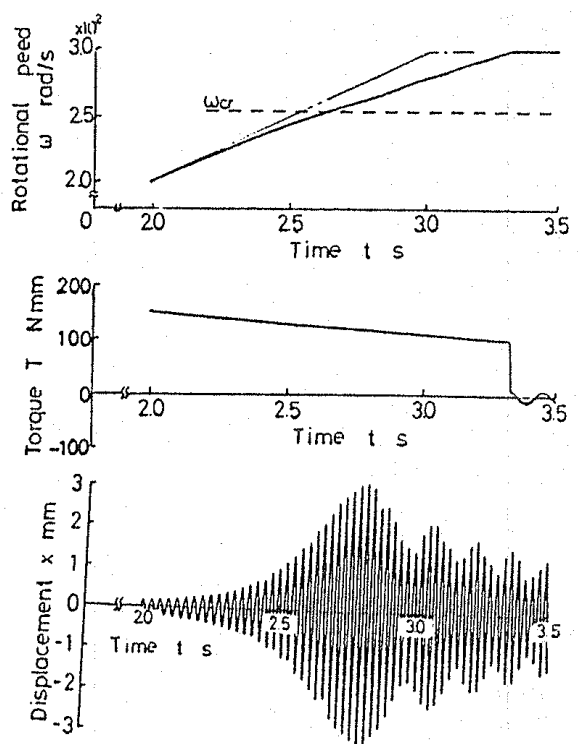

図 8 時刻歷応答と駆動トルク（定加速運転トルク制限大）
ていることがわかる。この埸合，ロー夕のふれまわり

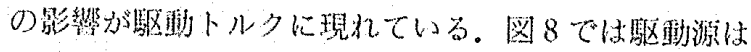
常に最大トルクな供給しているにもかかわらず，設定 加速度を維持することができない。この埥合トルクは 牂動源のトルク特性を示した右下りのものとなる。

图 9は图 7 と同じトク特性の系に対して，图60 型り運転明線で蛐転したものである。この場合は設定
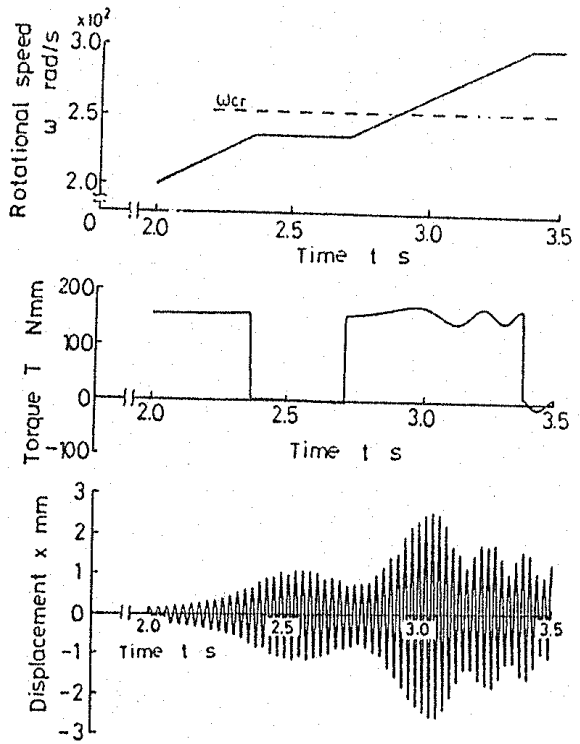

図 9 時刻歷応答と駆動卜ルク（図 5 の型の運転)

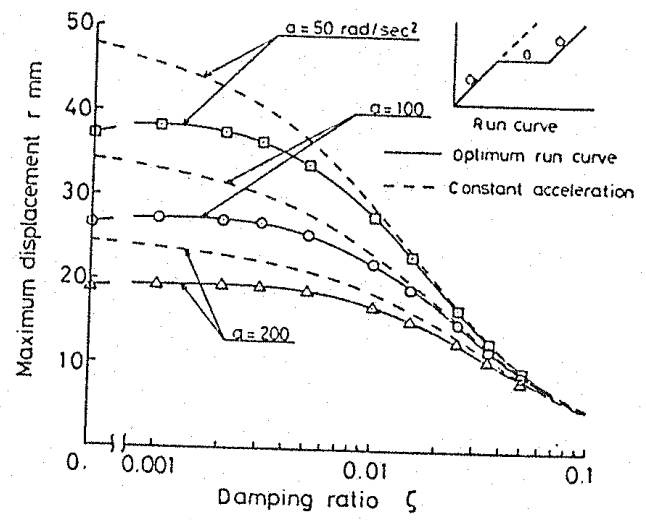

図 10 減衰比に対する最大ふれまわり

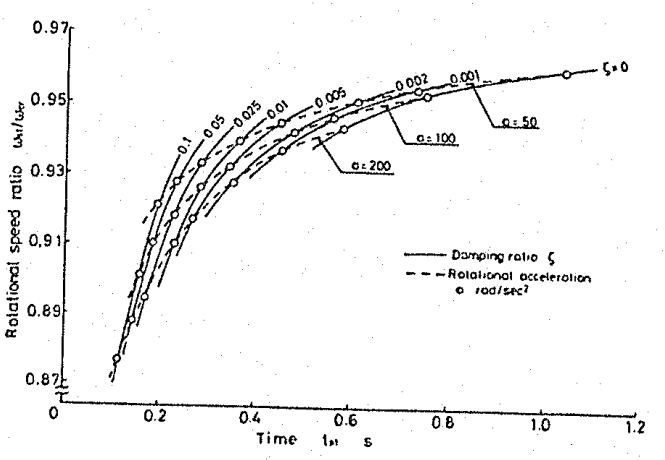

図 11 㞄転曲線の最適値 

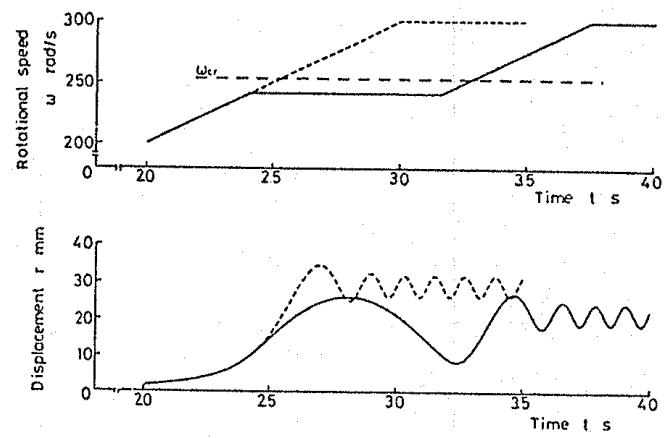

図 12 最適運転曲線による挙動

した運転曲線を維持できしかもふれまわりの最大振 幅の値が減少していることがわかり，この型の運転曲 線は効果があることがわかる。

$5 \cdot 2$ 運転曲線の最適化二つの設計変数 $\omega_{s t}$, $t_{s t}$ に対して，3章で述べた最適設計を行い，減衰，角

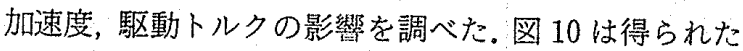
最適運転曲線で生ずるふれまわり振幅の最大值と減衰

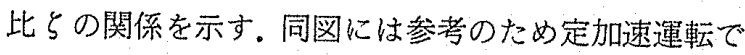
生ずるふれまわり振幅の最大值も示してある。減衰が 小さいと最適運転曲線によるふれまわりの抑制効果は 大きいが，減衰が大きい場合にはその効果があまり期 待できないことが判明した。

図 11 は，角加速度 $a$ と減衰比 りこつの設計変数 $\omega_{s t}$ と $t_{s t}$ の関係をみたものであ る.

図 12 は計算で得られた最適運転曲線を用いて危険 速度通過時の時刻歴応答を計算したものである。図の 実線樶適運転曲線に彷うものの最大值で, 破線は定 加速運転の場合で比較のために示した。危険速度通過 直後のふれまわり振幅が抑制されていることがわか る.

图 13 は，二つの設計変数を雨軸にとり，目的関数 $r$ の值の等しい点を結んで作成したものである。この計 算は箺験值と比較するために行ったものであり，プロ ットは実験値を示す。プロットは定加速連転の場合の $r_{\text {con }}$ との比で区別しており,$r / r_{\text {con }}<1$ の場合が抑制 效果の認めら机る場合である、×印が計算の最邀值て

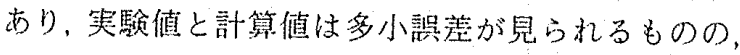
よく傾问が一致しているといえる。なお駆動トルクの 回転数繁のときの值による比較も行ったところ, 隇朢 比の大小によって危险速度の通䧟できる踇界のトルク の値が翼なることがかかった。

\section{6. 結誩}

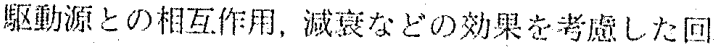

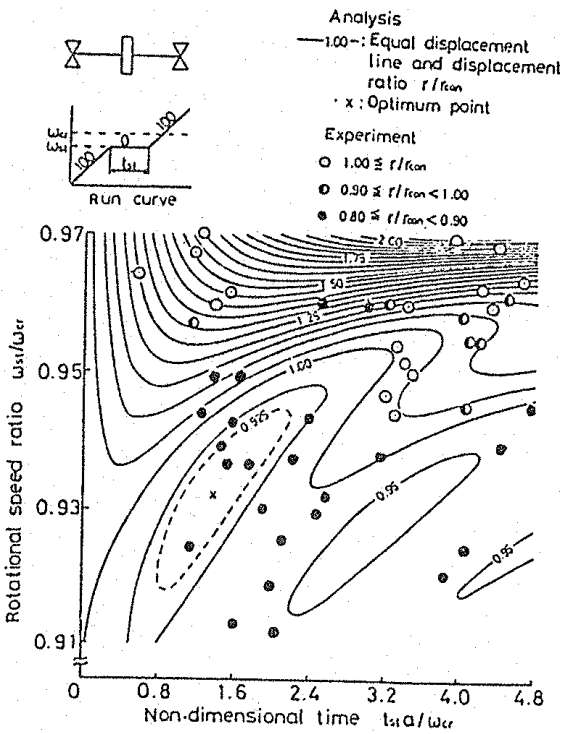

図 13 目的関数の様相

転軸系の運動方程式を導き, その時刻䃌応答解析法と して, ニューマークの $\beta$ 法とニュートン・ラプソン法 を併用する方法を提案した。 また危険速度通過時のふ れまわり振幅を抑制する目的で，実用的で効果が大き いと考えられる危険速度の直前で一畤的に停留する定 加速度型の運転直線に着目して，そのパラメー夕を最 適化手法によって決定し，各種の検討を行った結果，

（1）加速度や減衰などが最適な運転曲線に及ぼす 影響を解明した。

（2）最適運転曲線によるふれまわりの最大振幅の 抑制は，軽減衰系では効果が大きいことがわかった。

（3）奏騒的にも最適運転曲線による抑制効果が確 認された。

などの結論学得た。

なお本研觉の奏行に対し，冨重なご助言をいただい

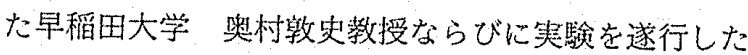
加筙正萃, 村上誠爾雨玨 (現在, 早稻田大学大学院在 学中）に深く感謝する。

\section{文献}

(1) Kononenko, V. O., Vibrating System with A Limited Power Supply, (1969), 11, London Iliffe.

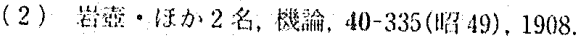

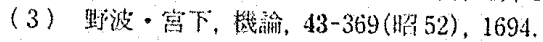

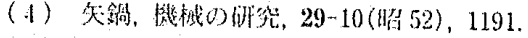

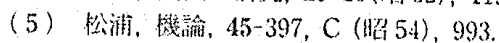

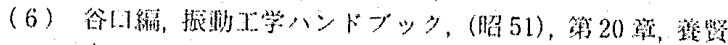
堂: 


\section{討}

[珤問]水谷一樹 (三雷大学工学部]

駆動源と回転軸乔との相互作用に関する研觉につい て與味深く扯兌した。

（1）運動方程式(7)，(8) の在辺の-(1/2) $I_{p} \ddot{\theta} \varphi_{y},(1 / 2) I_{p} \ddot{\theta} \varphi_{x}$ は，そ礼でれ， になることがオイラーの運動方程式加ら得られてい る(付1)。著者のご見解をうかがいたい。

（2）一般に駆動源のトルク特性は非線形になると 思うが，そのような場合にも本解析手法はそのまま邀 用できるのか。

（3）最適運転を与える運転曲線として図 6 の曲線 を採用された理由を㝀教え願いたい。また，回転軸系 のパラメータ(特に, 減衰)によって最適運転を与える 運転曲線の形が変わるというようなことはないのか.

(回答〕：（1）本論文の凮体円板が付加した回転 弾性軸の運動方程式 (7)，（8）はご指摘のように文献 中のものとは $1 / 2$ の係数の有無による相違がある。ま たご指摘いただいてはいないが運動方程式 (4)の右辺 の第 3 項に相当するものが同文献にはない.この相違 は近似方法の相違にあるものと考えられる、すなわ方 本論文では運動エネルギーの評価の際に $\varphi$ の三次以 上の項を無視してラグランジュの運動方程式に代入し て定式化しているのに対して，同文献はオイラーの方 程式そのもので $\varphi$ の二次以上の項を無視して定式化 していることに起因している。両方法の精度は，さら に高次の項を採るなどして比較する必要があり，問題 によっても異なるように思われる。なお同文献の著者

\section{論}

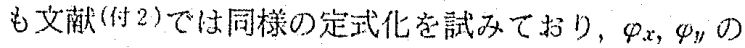
二次以上の項を門視する前では，式 (4)に相当する式

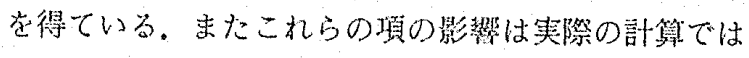
非常に小さいこと学付言してかく。

（2） $2 \cdot 2$ 節の記述路 4 の計算手䐓中に見られる ように微小時間間源ごとに提唱した方法では対象系を 区分線形化して応答を逐次求少るという方法を採って いるので, 非線形のトルク特性や幾何学的方るいは材 料的非線形性も考虑して比較的精度の良い近似計算が できる。

（3）本論文の延長線上にある問題として, 駆動源 との相互作用を考慮したうえで危険速度通過時の応答 振幅を最小化する大局的な意味での最適運転曲楾の決 定問題があり，筷者らも大変に與味を持っている。し 加しその問題には,トルク特性, 初期加速度, 危険速 度通過時の加速度，減衰など多くのパラメータを含み， まだ十分に検討できていない，本諭文ではその前段階 として, 奏用上直線的な加速運転は設定しやすいこと や，図 7 と図 9 は比較の一例であるが, 初期加速度と 危険速度通過時の加速度は一定にし，トルクは右下が りの特性を考えて試行的に計算や実験を行った結果の 両方汃ら，図6の形の運転曲線を一つの候補として， 最適化を行い検討したもので，いわゆる大局的な意味 での最適運転曲線の検討は残念ながら行っていない.

(付 1) 山本 - 河野, 機墖, 35-278（昭 44）, 2044.

(付 2) Yamamoto, Y., ほか2名, Mem. Facul. Eng. Nagoya Univ., 24 (1972), 7. 